\title{
Report on dwellings of Qing Dynasty in Poli village, Zhanbei, Xiangcheng county in Xuchang of Henan, China
}

\author{
LI Hongguang ${ }^{1, ~ a ~, ~ L I U ~ Y u q i n g ~}{ }^{2, b}$ and LIU Yufeng ${ }^{3, c^{*}}$ \\ ${ }^{1}$ School of Architecture,North China University of Water Resources and Electric Power, \\ Zhengzhou,Henan,450045,China \\ ${ }^{2}$ School of Electric Power ,North China University of Water Resources and Electric Power, \\ Zhengzhou,Henan,450045,China \\ ${ }^{3}$ School of Civil Engineer and Communication ,North China University of Water Resources and \\ Electric Power, Zhengzhou,Henan,450045, China
}

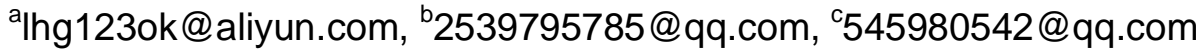

Keywords: Song-family Folk Residence; Red Stone Materials; Protection Proposals.

Abstract. Song-family folk residence at Xiangcheng County in Henan, China, applied composite bricklaying technology of the red stone and brick, having formed its special style. The building group has a considerable scale, and is well preserved. In the paper, we describe the characteristics and layout of them. We want to figure out the contents and conditions that had created them. Furthermore, we try to get more attentions and further protection on them.

\section{Introduction}

Located in the central area of Henan province, Poli village is located at Zhanbei township in Xiangcheng county. It lies in the south of Shoushan mountain, the first branch of the eastern Funiu mountains, with Zhan river in its south and NO.311 National Road in its west side. Poli village is flat and has quite convenient transportation. Song-family folk residence, the representative of folk dwellings community of Qing dynasty here, has a certain history and scale, and is a typical representative of courtyard houses mixed built with brick and stone in the middle part of Henan province. In June 2009, Song-family folk residence was listed as a municipal-class cultural relics protected units by the people's government of Xuchang city.

\section{Distribution and Composition of Folk Dwellings Community}

The dwellings of Qing dynasty are concentrated in the east-central region of the village. Under the control of north-south axis, 5 courtyard houses had constituted a rigorous in structure, well - balanced and extraordinary building community of Qing dynasty, in which the North is higher than the South. Its composition and structure are described as below: The first west courtyard house, owns the surviving main building in the northernmost(The interior has been burnt in a few years ago, only walls survived) and the west wing building (People are still living there so far). Some low level wings still remain in the middle yard, but have changed a lot later. There is also an old cypress in this yard. This courtyard house has the shortest north-south axis. The second west courtyard house, barely retains three hall rooms in the middle yard. One west passing-room, and three east wing-rooms remained too. The southern yard has three west wing-rooms. The north yard is great, with the same depth as the third west courtyard house, the buildings have gone yet, only the east gable wall and parts of the wall base survived. The third west courtyard house is very unique. Its door opens to the north side, gatehouse is in the northeast corner, having made a linear pattern with north house, while the roof is higher than the north house, showing out a case of gate-tower building. This practice is the common mode in the middle part of Henan province. Though being tall and great, the north house is a single storey of three bays. The south yard reserves some wing-rooms. The middle courtyard house is also the Song-family folk residence indicated on the mark tablet of cultural relics. It's located in the core place, and is the largest, highest-form and richest-decorated residence existing in the village, whose exact age having been identified by experts. The east courtyard house, is next to the middle 
courtyard house separated by the north-south road of the village, located in the southerly position. Three bays with two stories of the main north building, east and west wing-rooms with the same form and different size still exist now.

\section{The Characteristics of The Composition of Monomer}

All main buildings and wings in main(core) yards adopt a pattern of two-storey of three bays. On the one hand, this layout can provide more living facilities, meeting the demands of fame families; on the other hand, in size and scale, it also establishes the core status of main yard in the building group. According to preliminary estimates on the scene: The guest house building in the forth yard of the middle courtyard house is about 11.36 metres in width, the west wings are about 10.15 metres in width, both larger than the common buildings' width in the middle area of Henan province. In the south of the west wing, there is also a single-storey west wing of three bays. So, this courtyard is both wider and deeper, coordinates the relationship of residential buildings on the west, north and east three sides completely. Although main buildings are tall and grand, the courtyard is still wide, creating a dignified, relaxed atmosphere in space, full of great ingenuity.

Emphatic composite bricklaying technology of the red stone and brick. Red-stone foundation is used in all buildings, which usually has 5or 6 layers, for a maximum of 11 layers, caulking with white lime. The stones had been processed finely, its surface was chipped to flat without polishing, forming a surface with certain rough texture. All stones are of one uniform size, and have fine appearance and high flatness. Buildings are all in flush gable roof. The regular bands made of red stones and bricks appeared on the solid external walls, red stone bands with a certain roughness and plain bricks show a striking contrast in color and texture, while the true feeling and the sense of masonry between them are very coordinated and unified, as shown in Fig.1. Mixed with grandness and delicate feeling, this approach is just the taste of the culture of the central plains. It has became an important feature of the appearance of dwellings of Qing dynasty in Poli village, and is also an outstanding performance about the regional architecture style. The specific approach is: usually lay a red stone band circling the building every 7or 9 layers of bricks (it's similar to the ring beam in modern architecture), whose height is about 2 layers of bricks, forming red stone bands of interval distribution on regular in the brick walls of the building (there are 4 bands in single storey building, more in multistoried building). Through the internal structure, it was walled up regularly by red rectangular stones of facing bond and "Bashi" stones (Sewing the different materials) of stretching bond who have a square section, having made a crisscrossing, steric-interacted tie system by combined the stone bands with the brick layers in upper and lower, and the internal adobe brick layers, to ensure the integrity and strength of the composite wall (all walls here are in the pattern of " unripe bricks on the outside while ripe ones on the inside")(Fig.2). In the later time, the buildings adopted an improved practice by using the corner stones and "Bashi"stones. With the reduction of stone bands, stone dosage was reduced accordingly, as a consequence, the construction cost reduced.

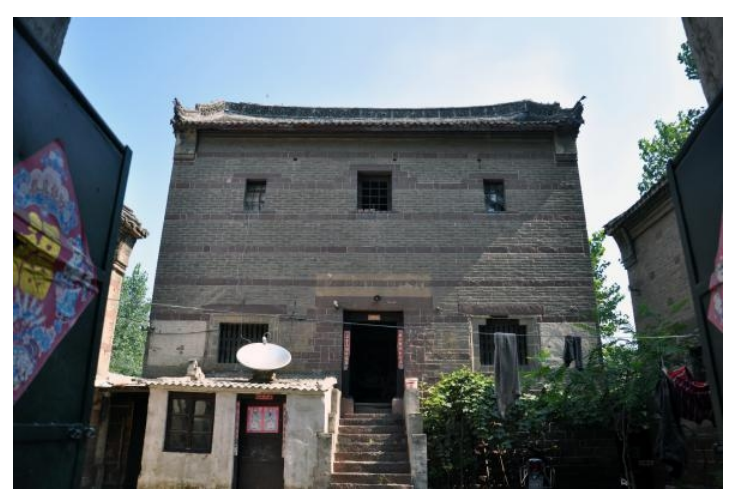

Fig.1 Regular bands of red stones and bricks

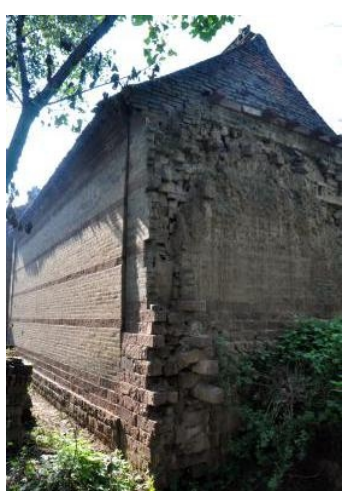

Fig.2 Composite bricklaying technology of red stones and bricks

Grand main hall buildings and luxurious decorations. Under the southern eave of the main hall, there are rich carvings and colored drawings, the building is magnificent and spectacular. Three -bay 
buildings are all equipped with sparrow brace with sculpture, which is caved out of a whole piece of wooden board, full of mascots like peony, grapes, pomegranates, magpie and so on. Ornaments of high relief figures, pavilions, celestial beings and clouds, Chinese words about happiness and longevity and other decorative items can be seen on the beam board. Orderly in layout, and superb in carving, Fig. 3 shows the exquisite wood carvings. The interior roof is erected by two-leveled beams. There are openwork carving clouds on both sides of the upper shorted column. There seem to be some pictures and texts at the bottom of the lower tie-beam of main ridge, but have been indecipherable. Colored drawings are painted everywhere on the beam and architrave, colors of red, blue, white, other in which can still be identified, presenting portraying themes like courtyard life, gardens play, landscapes and pastoral life. The best-preserved drawings are in the east room, describing various scenes of life: accompanied by servants holding the guard of honor, officers walked on the platform, watching crane dancing and deer drinking water; officers entertained guests in the hall, elaborate scenes of home furnishings, furniture and carpets can be seen; the woman looked around leaning upon the gate; pedestrians talked on the street. All scenes were depicted vividly.

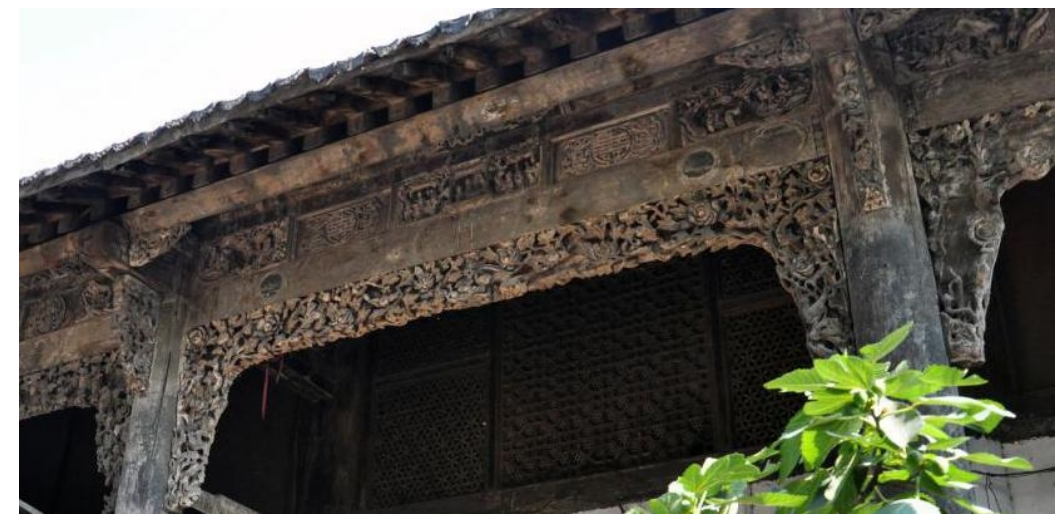

Fig.3 Exquisite wood carvings

Parallel main building, annex building and back garden are all set in the folk residence. Take the middle courtyard house for instance, at the location of the main building in the forth yard, guest house building, kitchen house building and gatehouse building stand close to each other, making a linear pattern.

Tight security. The relative altitude between the interior and the exterior of main building is about 1.5meters. The building looks tall and solid. Besides the facade, windows of the rest parts in the building are small, and only in the second floor. There is only one main door of solid wood, a circular perforated stone to lock the gate with stick, entirely paved in the wall, is correspondingly arranged on both sides of the inner part. From the actual observation, we can see that: the effective protection thickness of the main door is equal to the thickness of the wall (about $60 \mathrm{~cm})$, and the height is equivalent to 2 layers stones. The door is still intact, solid and reliable. The first-floor windows have three protection layers: the bricky window bar on the outermost layer, a wooden grille on the middle, and wooden window bar on the inner. The second-floor windows also have three protection layers: flat iron bar grille on the outermost layer, a wooden grille on the middle, and wooden shutters on the inner.

\section{Analysis of The Group Characteristics}

Multiple courtyards coexist, and rigorously ordered in layout. Although located in ordinary village, dwellings of Qing dynasty in Poli village had a strong official background, the 5 existing courtyards made full use of the advantages of plain terrains, spreading out along the north-south axis, and expanding in both east and west directions. Well-ordered with clear priorities, the dwellings has fully demonstrated the official background and style of the Song family. Villagers there said, only several years ago, it might be larger in scale than the famous Qiao Family Courtyard in Shanxi province. 
Buildings according to local conditions and life atmosphere. The dwellings have the characteristics of architecture in plain areas, like spreading horizontally, spacious courtyard, wide space, and the characteristics of buildings, in which, living space developed vertically, owing to a larger family in thickly populated areas and the demand of more living facilities, prominently representing the residential style in the middle part of Henan province, where it has a long history and a flexible, open, developed economy.

Outstanding architecture style and distinctive characteristics. The buildings have a large size and magnificent shape. The treatment of facade built of red stone and brick has formed its special style. The use of local materials is often one of the important methods of regional architecture characteristics. Shoushan mountain was the only one place industrially producing red-stone building materials in the history of the Central Plains. Thus, it had formed a limited area of the redstone-styled buildings distribution, which took the Shoushan mountain as a center of radiation. According to our research results in recent years, it's an area with center at Shoushan mountain and radius equal to 25 $\mathrm{km}$, including the whole Xiangcheng county, Southern Yuzhou county, Eastern Jiaxian county and Northeastern Yexian county. In the traditional architectures of above all areas, though the use ratio of redstone is different, the characteristic of built of red stone and brick is common. Dwelling of Qing dynasty in Poli village is one of the outstanding representatives.

Considerable in scale, detailed in construction, the building group is basically complete. Despite differences in scale and shape, maybe also in building age, the 5 building groups adopted a unified model, coordinative in plain organization, particularly all used the facade style of built of the red stone and brick, forming a unified style and a strong sense of community. The inheritance of design and building, also provides a relatively complete specimen for the research of transmission and evolution in the traditional construction technology of local architecture.

Well preserved, and still in normal use. Under the circumstances of maintenance and moderate reinstatement, we advocate the life use for these buildings, in order to show amazing vitality of ancient houses in a " live" condition. This can also promote a new method of cultural relics protection about the scattered and lonely folk houses.

\section{Proposals For Protection and Improvement}

Complete and enrich the protection content. Bring the first western courtyard house, the second western courtyard house and the third western courtyard house into the protection area clearly.

Strengthen the management and service. Prevent stealing and selling activities. Give the users costs and subsidies of protection and maintenance of cultural relics. Establish village group of cultural relics protection, make clear the responsibility and working system to peoples there.

Enhance the protection and daily managements.

Appropriate fund to solve the problem as soon as possible .

Strengthen environment improvement, safeguard people life and safety of the relics . Coal mining caused subsidence in this area, which has led to cracks in the buildings of traditional dwellings.

Propagate the dwellings strongly to extend influence.

\section{References}

[1] Guxi Pan,A History of Chinese Architecture, In Chinese, China Architecture \& Building Press, 2004.

[2] Manchang Zuo,Xianchen Bai, Folk Dwellings in Henan, In Chinese, China Architecture \& Building Press, 2012.

[3] Zhihua Chen: A History of World Architecture (before the end of 19th century ), In Chinese, China Architecture \& Building Press, 2004. 